\title{
SIMULATION ANALYSIS OF RISK MANAGEMENT FOR A DIVERSIFIED COMMERCIAL FARM
}

\author{
D.J.C. Malan' 1 A. Louw² and C. Blignaut ${ }^{3}$
}

\section{ABSTRACT}

Managing a profitable commercial agricultural business requires more than effective budgeting and financial bookkeeping. Due to dramatic changes in the agricultural decision-making environment over the past 15 years, farmers have to realise that farming requires effective risk management. A successful farmer is one who can identify these risks, match them up with expected returns and make the best decision on future actions. The farmer must be able to look strategically into the future and position the business in a way that ensures long-term sustainability and survivability. To forecast effectively, it is vital for the agribusiness to predict the effects of various risks on the financial position of the business.

This research attempts to develop a simulated dairy management model that can be used as a farm management tool. Normal distributions were used to simulate the movement of maize prices under different scenarios. This model was applied to a 2007 case study, and it was found to be a suitable tool for financial analysis and scenario planning. By utilising different sets of input values, the model gives an indication of the possibility of risks involved in different scenarios. However, the model is in a rather crude form, and further development should be undertaken to account for the interaction between variable inputs. The model highlights the importance of a change in strategic direction, while it is useful in analysing the scenario outcomes of new strategies.

Key words: Risk management, dairy, simulation

According to Ferguson (1990), the agricultural fraternity has protested against forecasting, claiming that "effective forecasting in my situation is impossible so why bother"? Farmers are willing to take huge risks in the hope of realising high prices for their products, betting against the odds without having any idea of the odds. Van Zyl, Kirsten, Coetzee and Blignaut (1999) warn that South African farmers should produce what the market needs and not focus on production aspects alone.

The most important aspect of management proficiency is the ability to forecast a business path and implementing, monitoring and controlling it on a daily basis with the purpose of achieving projected objectives. If this is done effectively and accurately, the business's financial performance will be a result of management's 
planning and execution and not just the result of favourable commodity prices or weather conditions.

Financially, a successful farming business depends on its internal balance of assets, liabilities, revenue, expenses and cash flow (Van Zyl et al. 1999). Unfortunately, many South African farmers and their accountants only use this information for tax returns and not to determine the current (ongoing) financial state of their businesses, or know how to use this data for proper planning and budgeting purposes. It is not only important to apply and interpret the mutual interaction between these statements and resources, but also to match the farmers' accepted risks and the consequential expected return (Hardaker et al. 2004). Commercial farmers need to understand all the components of risk and be able to put together comprehensive risk management plans (USDA 2000).

With a sound financial system consisting of properly designed and integrated income statements, cash flow statements and balance sheets, it is possible to manage an uncertain future, which would enable one to make decisions with better insight. Using such formatted financial data, a farmer can create a possible future scenario against the backdrop of possible risks the business might face. To achieve this, simulation techniques can play an important role (Ferguson 1990).

The next section consists of a synoptic literature study on risk and risk management, as well as a Monte Carlo simulation, followed by strategic management issues and brief details of the case study where the simulation's results are applied. An assessment of risk management strategies and certain recommendations are given in the final section.

\section{METHODOLOGY}

An extensive literature survey was done and information used on risk and risk management provided by the United States Department of Agriculture. Financial analysis was based on the work of Ferguson (1990) found in his classic book on successful commercial agriculture and also the monthly Ag-Report newsletter published by the Ferguson Group in the United States (Ferguson 2006).

A case study, based on the financial information from Rusticana Farming, an agribusiness situated near Bethal in Mpumalanga, South Africa, was used to demonstrate some of the aspects of risk management and financial analysis. Three simulation software packages, XLSim ${ }^{\circledR}$ from Microsoft ${ }^{\circledR}, @$ RISK ${ }^{\circledR}$ from Palisade ${ }^{\circledR}$ and TopRank ${ }^{\circledR}$ from Palisade ${ }^{\circledR}$ generated data for Monte Carlo simulations.

Risks that Rusticana Farming faced were analysed with Monte Carlo simulation techniques. This simulation process per se involves utilising a cumulative distribution function to generate random output values, the number of which is dependent on the number of iterations, in order to calculate probabilities 
that a simulated outcome will have a certain probability of occurrence (Hardaker et al. 2004). The principle of sampling from a uniform distribution is based on the frequency interpretation of probability, in other words, in the long run the outcomes must occur with the frequency specified by the probabilities in the distribution (Winston 2003).

In simulation modelling, the planned outputs and stochastic variables (inputs) are identified, and a high number of iterations of the model produce an approximation of the probability distribution for the stochastic variables and outputs, or payoffs, for different alternatives. The final results will be both risk profiles and average outcomes, which could be extrem ely useful in risk and decision analysis (Clement 2001). These risk profiles are used as a sensitivity analysis, to test the sensitivity of the key output variables with regard to various stochastic costs and incomes. The risk profiles were conducted and the sensitivity analysis is represented graphically. The financial model and Monte Carlo simulations are subsequently used to recommend and evaluate various risk management strategies for Rusticana Farming.

\section{LITERATURE STUDY ON CORE CONCEPTS \\ 3.1 Risk and return in business}

A business exposed to the possibility of a good or a bad outcome faces risks and is deemed a risky prospect. In other words, there is uncertainty about what the outcome could be (Miccolis et al. 2001). Risk is defined as quantifiable uncertainty that affects a business's welfare and is often associated with adversity and loss (Harwood et al. 1999). When the probabilities of possible outcomes of a risky prospect are known, risk is imperfect knowledge. Uncertainty exists when these probabilities are not known. It has no quantifiable value (Hardaker et al. 2004). The following perception of risk and uncertainty is similar to the latter definition, namely, that risk is present when future events occur with measurable probability, and uncertainty is present when the likelihood of future events is indefinite or incalculable (Casavant 1984; Lohano and King 2009; Atwood and Buschena 2003).

Every business that is confronted with risky decisions should know the consequences of its decisions, that is, the magnitude of risk accepted, which means that the business must know the probability of how much money can be lost or gained on any given venture. Most studies, analyses and developments regarding risk-measuring tools and techniques are used by professional portfolio managers instead of farmers (Atwood and Buschena 2003; Stephens 2001; Hailu, Jeffrey and Unterschultz 2005; Olynk and Wolf 2009).

The Monte Carlo simulation technique was used to measure and analyse risk for the Rusticana farming business. 


\subsection{Risk management in common agriculture}

Agricultural risk management, in general, involves finding the combination of activities most preferred by an individual farmer for achieving the desired level of return at an acceptable level of risk, that is, improving risk efficiency (Dismukes and Harwood 2000; Hardaker et al. 2004). When applying risk management strategies, the farmer aims to reduce risk within the farming operation (through diversification or vertical integration), and through transferring a share of the risk outside the farm (making use of insurance schemes, production contracting or hedging), or building the farm's financial capacity to the point where it is able to manage higher levels of risk (by maintaining cash reserves). The best risk management strategy does not intend to eliminate risk altogether, as in all businesses a certain measure of risk retention is a given. However, it is possible to balance risk and return with the farming operations' capacity to absorb a wide range of outcomes or, stated more technically, by increasing the farm's risk efficiency (Lohano and King 2006; Atwood and Buschena 2003; Hardaker et al. 2004).

Farmers should be concerned about risk management, since the consequences of their decisions remain uncertain long after those decisions are made or actions carried out. Outcomes of their risky decisions may be better or worse than expected, therefore, a sound understanding and management of risk is essential in helping producers with decision making (Harwood et al. 1999).

\subsubsection{Sources and classification of risk in agriculture}

Sources of risk, well discussed in standard text books and scholarly papers, and dissertations on risk and risk management ${ }^{4}$, are subject to various classifications such as systemic risks and nonsystemic risks (Stephens 2001; Louw 2002; Van Zyl et al. 1999; Hardaker et al. 2004; Holmes 2002; Gudbrand 2003). The essence is that the identification of risks and their source is necessary to develop a risk analysis structure - to structure the problem - and contingency plans.

\subsubsection{Managing strategic risks}

Thompson and Strickland (2003) discuss and define strategic management, and concur that it is a process of identifying risks and evaluating the risks and benefits of all the possible strategic scenarios, and deciding which risks to avoid and which would be worthwhile accepting. Some examples of risk management strategies are the following: enterprise diversification and specialisation (Harwood et al. 1999); vertical integration (Mighell and Lawrence 1963); strategic alliances (Louw 2002); and the balanced scorecard approach (Venter 2003; Kars 2003). 


\subsubsection{Managing financial risks}

Many producers face price and yield risks that are important types of risk. Yield risk varies randomly and is dependent on soil type, climate, the use of irrigation and other variables. Commodity stock levels, international price levels and exchange rate variability determine price risk for a given commodity (Harwood et al. 1999; Gudbrand 2003; Hailu 2003).

Forward pricing can mitigate price risk very effectively, involving setting the price or a limit on price for a product to be delivered in the future. The most general types of forward pricing strategy are cash forward sale, futures and option hedges (Stephens 2001).

\subsubsection{Other risk management strategies}

Other strategies for managing risks include the management of yield risk, programme and project risk, operational risk and technological risk. It is not possible to devise a single generic risk management approach for all farms, but the strategies proposed can be used to gauge the likely effectiveness of various risk management strategies. The prime goal of any risk management strategy should be to protect the balance sheet by assuring that the net worth of the business does not erode (Kulak, Neilson and Strandbergh 2004; Atwood and Buschena 2003).

\subsection{Financial analysis}

A lack of knowledge of the true financial position of a business is one of the main reasons why agricultural businesses fail financially (Ferguson 1999). Without quality information organised into relevant financial statements, financial analysis and planning will be futile. It will be virtually impossible to determine how risk and uncertainty affect the business if there is no baseline of relevant financial data to benchmark against. Furthermore, it is impossible to forecast the business's future path without relevant information. It is, therefore, important to establish a baseline for agricultural financial documents and measures of success that could be used in the proposed simulation model. These documents and measures include the balance sheet, income statement and financial ratio analysis (Atwood and Buschena 2003; Hailu et al. 2005; Olynk and Wolf 2009). The case study of Rusticana Farming illustrates how the effects of risks influence the financial position of the farmer. 


\section{THE CASE OF RUSTICANA FARMING \\ 4.1 Background and goal of research}

The relatively low farm-gate prices associated with agricultural produce and everincreasing input costs have placed many farmers in a difficult position. Margins are ever decreasing, leaving farmers with no margin for error in planning and budgeting. It is, therefore, crucial for farmers to consider the risks they are exposed to and to anticipate and analyse the risks they might face, so that they can plan ahead and put strategies in place to mitigate these risks.

Rusticana Farming is a commercial farming business divided into two farming units, namely, a dairy and a field crop unit. The dairy unit consists of a registered Holstein herd with 335 high yielding milk cows. The cows are in a zero grazing, totally mixed ration (TMR) system. The field crop unit consists of 757 ha of medium potential arable land.

The goal of this research was to build a financial model for Rusticana Farming with the ability to integrate fully all the aspects of the business's operational and financial management activities. Maize yields and prices in combination with milk prices are the stochastic variable inputs to the model. Applying the variations in inputs, the process interactively updates the income statements, balance statement and ratio analysis. Monte Carlo simulation created probability density distributions for the model's outputs. An analysis of the impact of different scenarios on the financial state of the business is based on these density distributions. Figure 1 illustrates the flow of information in the spreadsheet model.

\subsection{Model assumptions \\ 4.2.1 Price and yield inputs in model}

Maize prices are determined on the free market principles of supply and demand. Due to the limited market space for maize in South Africa, the price of maize is very sensitive to changes in supply. For this reason three scenarios of national supply were defined, namely, a small, average and large crop. The assumption is made that the area of crop to be planted in the $2007 / 2008$ season would change from that planted in the $2006 / 2007$ season. The scenarios are as follows:

\section{a) The "small crop" scenario}

In this scenario, the national maize shortage in South Africa is assumed to be 900000 tons. This would result in increasing imports and, subsequently, a maize price at or close to import parity. For this study, it is assumed that the price would be normally distributed, with an average level of R1 300 per ton, with a standard deviation of R100 per ton. 


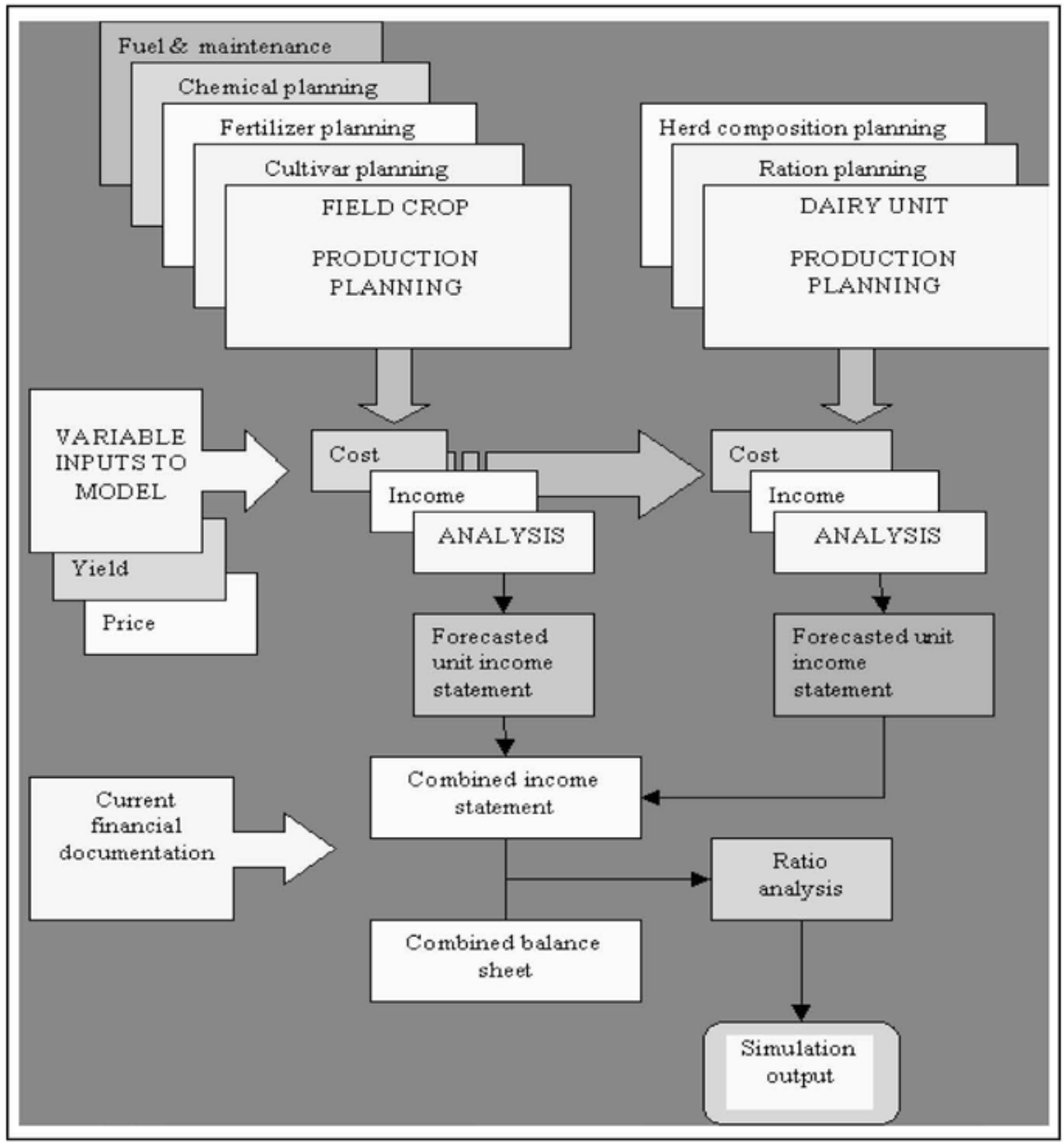

Figure 1: Model information flow

Source: Malan 2007

b) The "average crop" scenario

An average crop is assumed to deliver a maize surplus of two million tons. Exports to, mainly, the Southern African region will result in prices in the higher mid range between import parity and export parity. It is assumed that the average maize price would be normally distributed, with an average level of R1 200 per ton, with a standard deviation of R100 per ton. 


\section{c) The "large crop" scenario}

It is assumed that the maize surplus is in the order of four million tons. This means that the supply of maize is more than the needs of the local and export market in the Southern African region. The price would subsequently decrease to a level close to export parity. For this study, it is assumed that the price would be normally distributed, with an average level of R700 per ton, with a standard deviation of R100 per ton.

\section{d) Data and standard deviation of maize prices}

The data used were the contract prices for the 2006/2007 white maize contract (Safex 2007). From this data the assumption was made that the standard deviation stays approximately at the same level of R100 per ton for most Safex maize contracts. The standard deviation was determined through the application of a curve-fitting algorithm from @Risk software (Palisade 2001).

\section{RISK ANALYSIS USING MONTE CARLO SIMULATION}

The section below illustrates how different techniques can be used in calculating risk via a practical application.

Table 1: Rusticana: Summary of a Monte Carlo simulation

\begin{tabular}{|l|r|r|r|r|r|}
\hline Indicators & $\begin{array}{r}\text { Benchmark } \\
\text { (percent) }\end{array}$ & $\begin{array}{r}\text { Mean } \\
\text { (percent) }\end{array}$ & $\begin{array}{r}\text { Std.Dev } \\
\text { (percent) }\end{array}$ & $\begin{array}{r}\text { Probability } \\
\text { (percent) }\end{array}$ & $\begin{array}{r}\text { Range } \\
\text { (percent) }\end{array}$ \\
\hline $\begin{array}{l}\text { Gross profit on cash } \\
\text { revenue (GPOCR) }\end{array}$ & 20 & 16 & 2.74 & 90 & $12-21$ \\
\hline $\begin{array}{l}\text { Un-levered return on } \\
\text { investment (UROI) }\end{array}$ & $>10$ & 26.4 & 6.17 & 90 & $16-37$ \\
\hline Return on Assets (ROA) & 10 & 8.6 & 2.16 & 90 & $5-12$ \\
\hline $\begin{array}{l}\text { Earnings before int, tax, } \\
\text { depr, and amortisation' } \\
\text { (EBITDA) Rand }\end{array}$ & R2.4-R4.3 & R 2.14 & R0.37 & 90 & R1.5-R2.8 \\
\hline
\end{tabular}

1 Int = interest, depr=depreciation

Source: Malan 2007

\subsection{Gross profit on cash revenue (GPOCR) ${ }^{5}$}

The average GPOCR is four (4) percentage points less than the benchmark figure ( $16 \%$ vs. $20 \%$ ) and its coefficient of variation ${ }^{6}$ is 16.3 per cent, indicating a relatively low stability (Table 1). According to Ferguson (1990), low levels of GPOCR are a result of problems with the business's internal structure, which include assets, liabilities and sales, as well as inadequate expense control. 


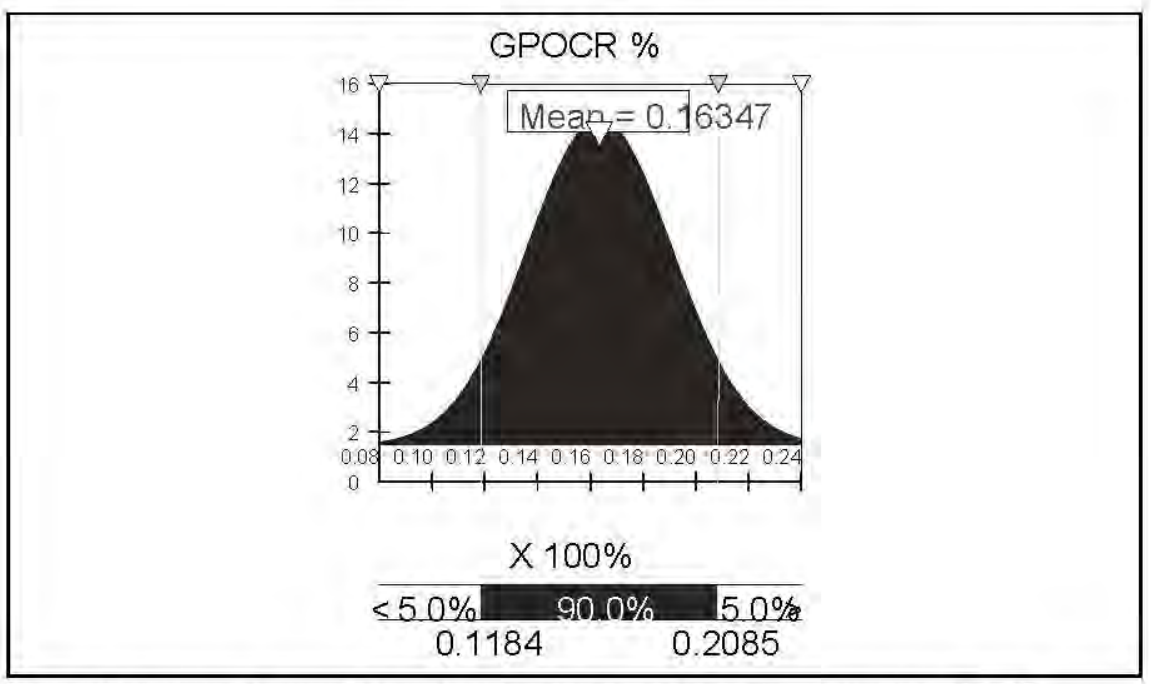

Figure 2: Rusticana farming. Normal distribution fitted to simulation data for GPOCR, 2006/07

Source: Malan 2007

The probability that the mean GPOCR will occur is 56 per cent, with a 90 per cent probability that the GPOCR can vary between 12 per cent and 21 per cent (Figure 2).

\subsection{Un-levered return on investment (UROI)?}

The UROI index measures a business's actual earning power, that is, return on investment in a debt free business, and consequently the effects of taxes and interest expense are excluded (Ferguson 1990). The UROI for Rusticana Farming is 26.4 per cent (Table 1 ), which is higher than a RSA dairy benchmark of levels of "higher than 10 per cent" (Maree, 2007).

\subsection{Return on assets (ROA) $)^{3}$}

This ROA level ( $8.6 \%$, Table 1$)$ is lower than the industry norms and returns of 9.4 per cent on twelve-month, low risk, money market securities (Anon 2008). These comparisons indicate that sales generated with the total investments are reasonably adequate. Ferguson (2006) states that the three major factors contributing to high profitability levels are economies of scale, investment strategies and debt utilisation (Mosheim and Lovell 2009). 


\subsection{Earnings before interest, tax, depreciation and amortisation (EBITDA) ${ }^{9}$}

The EBITDA index for 2007 is estimated at a level of two (2). In other words, 2.14 per cent of EBITDA is available for every rand of debt for which payment is due in 12 months and less.

\subsection{Debt payment index ${ }^{10}$}

The debt payment index of 4 per cent is low and thus healthy. It indicates that at the end of the 2006/07 period, R4 of debt principal plus interest should be paid for every R100 of revenue. This is better than the acceptable levels of 18 per cent benchmarked for South African dairy farmers (Maree 2007).

\subsection{Liquidity index ${ }^{11}$}

The simulated liquidity index for Rusticana Farming is extremely high at 604 per cent (Malan 2007) and is substantially higher than the South African benchmark ratio of greater than 2:1 or 200 per cent (Maree, 2007). The fair market value of the registered diary cows in Rusticana Farming during 2006/07 has very high levels, which are reflected in the high liquidity index.

\subsection{Leverage}

Maree (2007) states that the leverage ratio gives an indication of the farmer's ability to use his own funds to cover his liabilities. As a rule of thumb in South Africa, for a farm to sustain a healthy financial position the ratio should be 1:1 (Van Zyl et al. 1999). Rusticana Farming's ratio is an acceptable 1:1.19 at book value, and a debt equity ratio at fair market value of 1:3.69 as calculated (Malan 2007) consequently compares well with South African standards. The low level of debt to equity at market value suggests that the expected return on equity will be low but certain, that is, the financial risk and return in the business is relatively low.

\subsection{Sensitivity analysis}

TopRank ${ }^{12}$ was used for a sensitivity analysis for most of the key financial ratios and profitability indicators. The most important difference between TopRank and@Risk is that “@Risk studies show how the combined uncertainties of all variables affect the output. TopRank only tells how an individual input or a small number of inputs affects output". (Palisade 2005, pp. 478-479). Holding all but one variable constant in a TopRank calculation, the chosen variable is varied with a preselected percentage, in this case +10 per cent and -10 per cent of its rated 
value. One-way sensitivity trials were generated and these are illustrated in Tables 2 to 4 . Tables 2 to 4 represent the sensitivity of net income, gross margin and gross profit, respectively, to changes in variables affecting them, as indicated in the tables mentioned.

The dairy's net income, unit gross margin and gross profit on cash revenue's sensitivity for identified variables are summarised in Tables 2 to 4 . It is apparent that the feeding cost component of the variable dairy costs, be it dairy unit variable $\operatorname{cost}^{13}$ (Tables 2 and 4 ) or feeding cost of cows in milk (Table 3 ), is the single most important aspect to manage in this business.

Table 2: Percent change in net income related to $10 \%$ change in listed variables

\begin{tabular}{|l|r|}
\hline $10 \%$ change in listed variables & \% change in net income \\
\hline Dairy Unit Variable Cost & 52.4 \\
\hline Total Fixed Costs & 17.2 \\
\hline Field crop Unit Variable Cost & 9.6 \\
\hline Tax Payable & 5.4 \\
\hline Depreciation & 4.1 \\
\hline Interests & 0.9 \\
\hline
\end{tabular}

Source: Malan 2007

Table 3: Percent change in gross margin related to $10 \%$ change in listed variables

\begin{tabular}{|l|r|}
\hline $10 \%$ change in listed variables & \% change in gross margin \\
\hline Feeding Cost Cows in Milk & 33.4 \\
\hline Feeding Cost Heifers & 7.5 \\
\hline Other Operating costs & 7.2 \\
\hline Total Fixed Costs & 3.8 \\
\hline Feeding Cost Dry Cows & 3.2 \\
\hline Culled Animal Sales & 2.4 \\
\hline Feeding Cost Calves & 2.3 \\
\hline Day-Old Bull Calves Sales & 0.25 \\
\hline Breeding Bull Sales & 0.1 \\
\hline
\end{tabular}

Source: Malan 2007

The main GPOCR drivers are the number of cows in milk, milk yield, milk price and the input costs. 
Table 4: Percent change in gross profit (loss) on cash revenue related to $10 \%$ change in listed variables

\begin{tabular}{|l|r|}
\hline $10 \%$ change in listed variables & \% change in GPOCR \\
\hline Cows in milk & -44.2 to 37.9 \\
\hline Milk yield & -44.2 to 37.9 \\
\hline Milk price & -44.2 to 37.9 \\
\hline Dairy unit variable costs & 37.1 \\
\hline Total fixed costs & 10.6 \\
\hline Field crop unit & 5.9 \\
\hline
\end{tabular}

Source: Malan 2007

\section{RISK MANAGEMENT STRATEGIES \\ 6.1 Financial risk management}

Various risk management strategies are proposed and evaluated using the financial model and the Monte Carlo simulations.

\subsubsection{Managing price risk}

From the simulated results, it is evident that the price of milk (Table 4) and the price of feed commodities (Table 3) are the main sources of risk for this case study. The price of maize is the major cost factor in a dairy cow's ration and, therefore, the maize price is a major source of risk that requires careful management. However, since the diary farmer is a price taker in the value chain, the maize price is difficult to manage.

To manage these risks optimally it is necessary to evaluate several strategies. The first of these strategies is a hypothetically fixed maize price at a specific level. Simulation runs for the GPOCR with maize price levels set at R900/ton, R1 000/ton, R1 100/ton and R1 200/ton, irrespective of the crop size, are compared with the 2007 no interference price scenario. Figure 3 illustrates the cumulative distribution functions of GPOCR for these different maize price scenarios. 


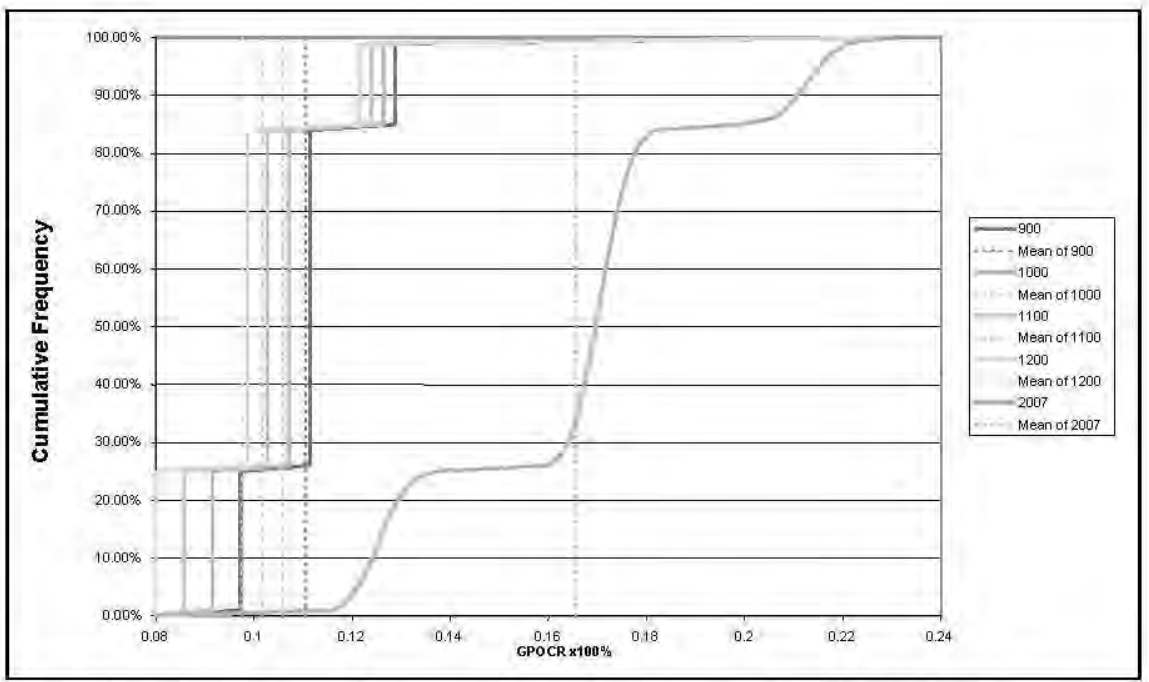

Figure 3: Rusticana farming: Cumulative distribution function of GPOCR for fixed maize prices compared to a no interference scenario, 2006/07

Source Malan 2007

The 2007 scenario (Figure 3) stochastically dominates the other outcomes, while the spread between the 95 per cent and 5 per cent probability lines (Figure 4 ) is narrower for the fixed priced scenarios than for the 2007 scenario. This can be ascribed to the natural hedge that exists in the farming business. The standard deviations for the fixed priced scenarios are 0.996 per cent, 1.1005 per cent, 1.2038 per cent and 1.3057 per cent, which are significantly lower than the standard deviation of 2.739 per cent for the 2007 no price intervention scenario. It is clear that the risk in the no interference scenario (2007) is higher, while the possible returns are larger. This indicates risk efficiency, as the utility (income) of the farmer is the highest and the 2007 scenario is first-degree stochastically dominant. 


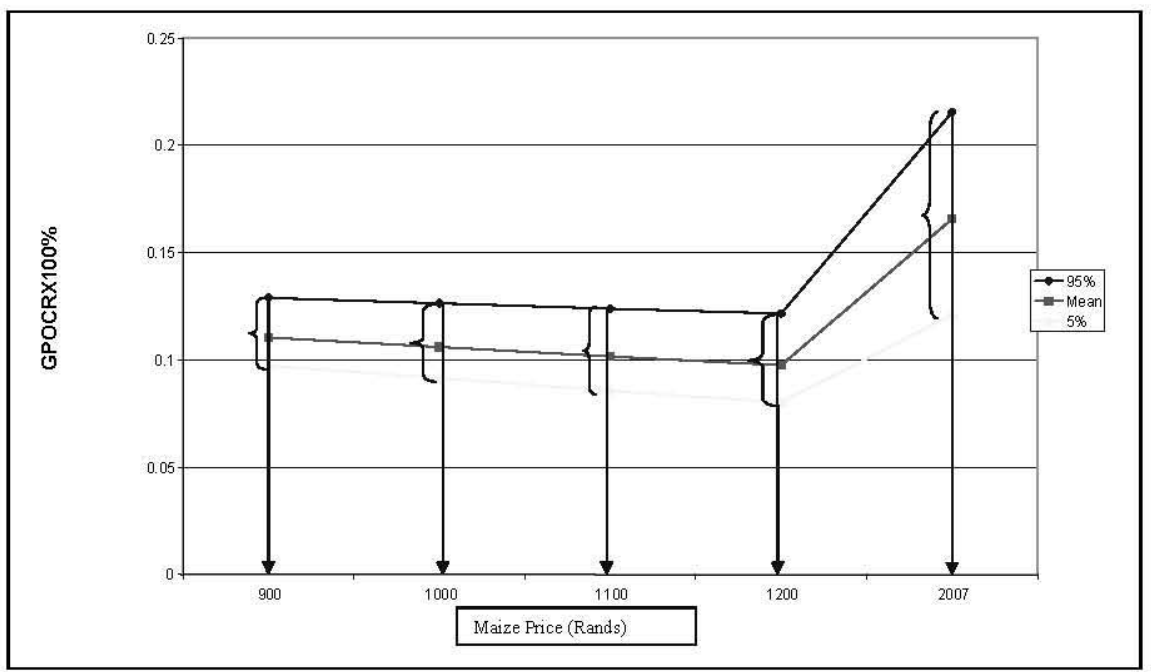

Figure 4: Rusticana farming: The $90 \%$ confidence interval for GPOCR with fixed maize prices, 2006/07

Source: Malan 2007

The second strategy considered in comparing the different GPOCRs is fixing maize price bought for feed at the levels given above and not interfering with the field crop unit's maize selling price. The 2007 outcome was the benchmark used to compare with the simulations results. None-stochastic first-degree dominance of the different price scenarios is present (Figure 5). However, taking into account the normal distributions of the simulations, the standard deviation of the GPOCR at maize buy-in prices of R900/ton and R1 000/ton is 1.3 per cent, which is less than the 2.7 per cent of the 2007 scenario. Buying maize for the dairy at less than R1 $000 /$ ton can, therefore, reduce the financial risk of the farming business. However, this strategy does not reduce the risks involved with maize prices significantly, and seems to be unnecessary in the presence of the natural hedge that exists in this farming business. 


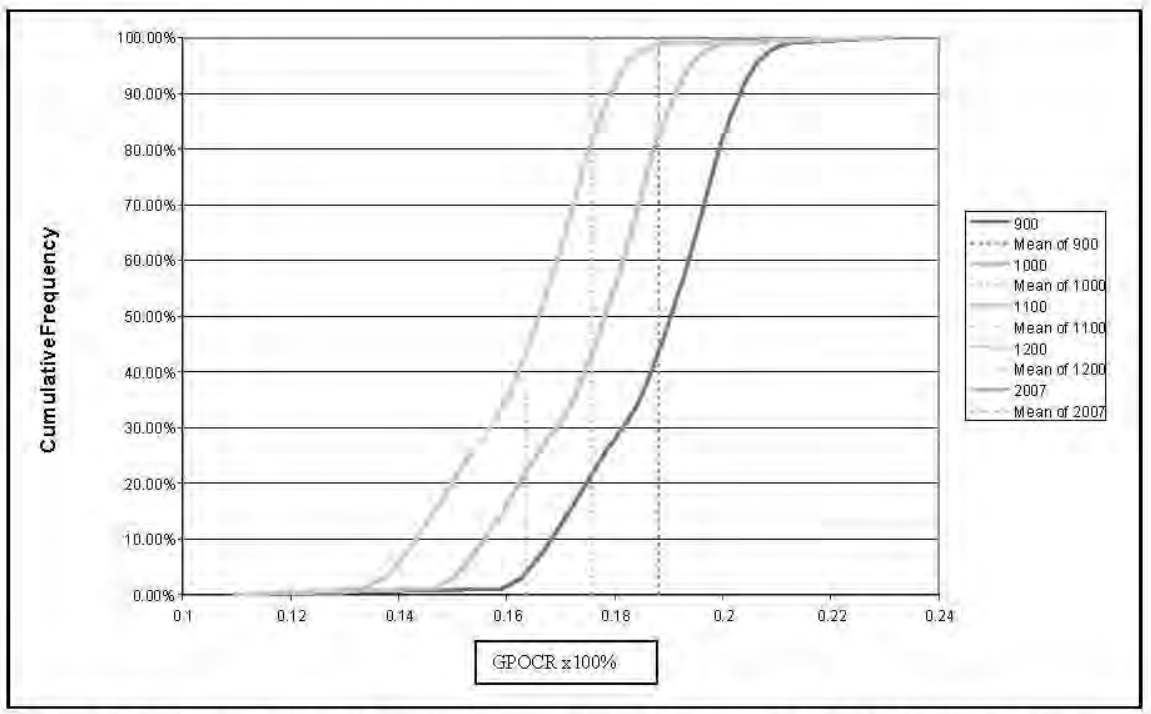

Figure 5: Rusticana farming: Cumulative distribution functions of GPOCR for maize buy-in with no interference with the selling price of maize, 2006/07 Source: Malan 2007

Applying the following assumptions in different simulations determined the strength of the natural hedge that exists in the farming business:

- Minimum yield for maize is one (1.0) ton per hectare;

- Prices can still vary according to assumptions made in the model;

- Milk price and yield stay constant.

Figures 6 and 7 respectively depict the cumulative distribution function for both GPOCR and the net income of the business in totality under a crop failure scenario. The expected long-term GPOCR level of approximately 16 per cent with a 2.7 per cent standard deviation decreased to an average of 9.6 per cent and 2.4 per cent respectively. Net income decreased to an average of R258 000, while the EBITDA index of 1.11 indicates that there would be R1.11 available for every R1 of debt, providing that debt levels stay the same. The conclusion is that, given the other assumptions underlying the model, a crop failure would affect the profitability of the farm negatively, but it would still be able to survive a crop failure, which is the single greatest risk it faces. 


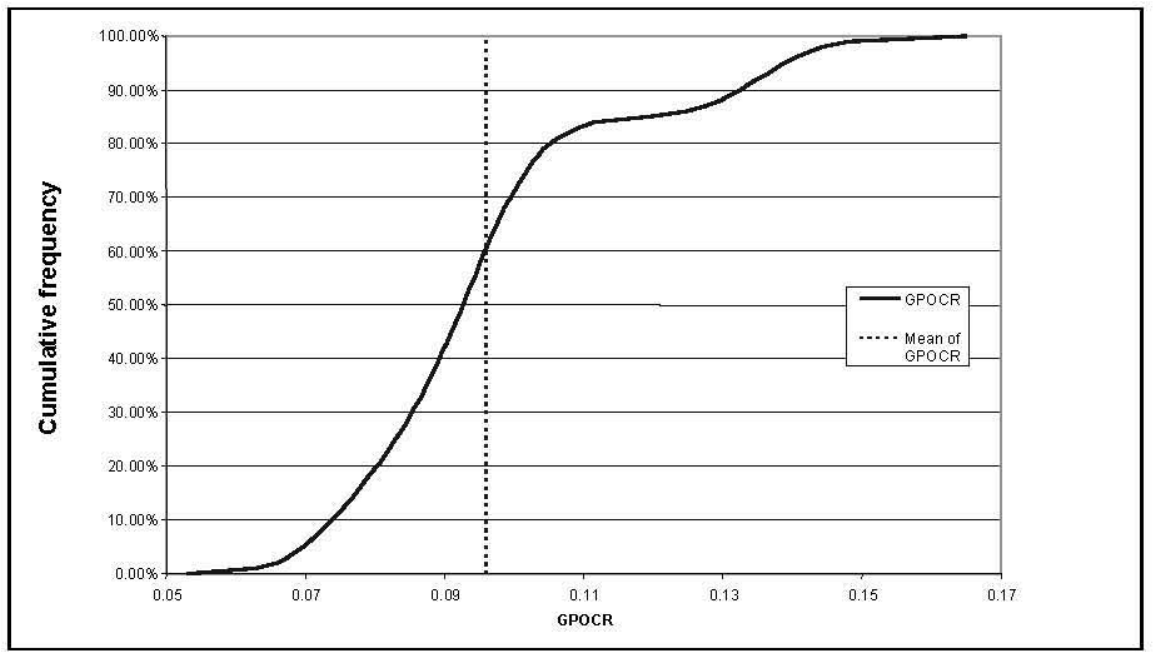

Figure 6: Rusticana farming: Cumulative distribution function of GPOCR for crop failure scenario, 2006/07

Source: Malan 2007

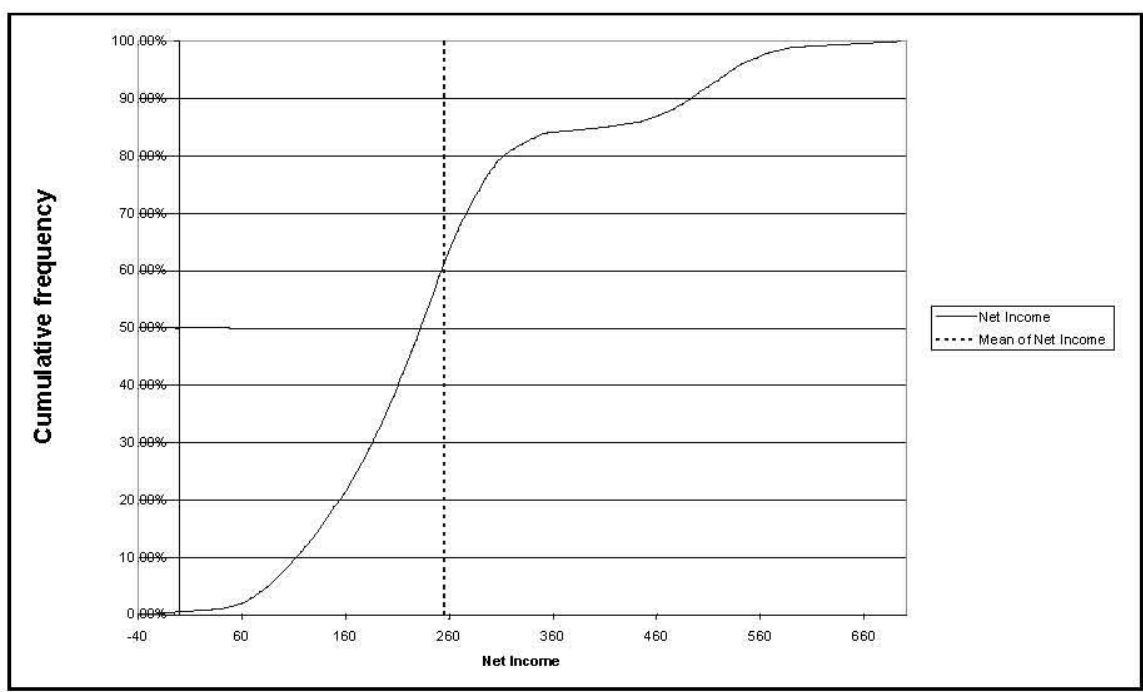

Figure 7: Rusticana farming: Cumulative distribution function of net income for crop failure scenario, 2006/07

Source: Malan 2007 


\subsection{Strategic risk management}

Evaluation of strategic management decisions based on the simulation model is as follows:

\subsubsection{Enterprise diversification or specialisation?}

From the conclusions drawn about price risk management, it is clear that Rusticana Farming is a well-diversified business. However, a significant decline in milk prices could result in a troublesome financial position for the business. An option considered is to sell the diary unit and specialise in maize production. In this scenario, the following assumptions are made:

- Sell all the dairy animals and the diary related equipment;

- Use the proceeds to finance the purchase of more farmland and equipment to effectively produce maize;

- The net worth in the balance sheet is assumed to stay the same;

- Plant an additional 1000 ha maize.

Running simulations for a maize specialisation scenario, calculating the GPOCR under the assumptions mentioned above, produced the cumulative distribution function in figure 8 . The mean of GPOCR is down from nearly 16 per cent for the diversified business to a mere 3.7 per cent for the maize specialisation scenario. In addition, the standard deviation at 13.4 per cent indicates a risky prospect, thereby making the specialisation scenario an unacceptable strategic option. However, by fixing the maize price at a level of R1 050 per ton through forward contracting, it is possible to combine the maize specialisation scenario with a price risk reducing strategy. The simulation of this combined strategy showed a decline in the GPOCR's expected mean value from 3.7 per cent to 2.28 per cent, but a decline in the standard deviation from 13.4 per cent to 11.9 per cent. This manifests the theory that the less the risk (standard deviation), the less the profit propensity (GPOCR). 


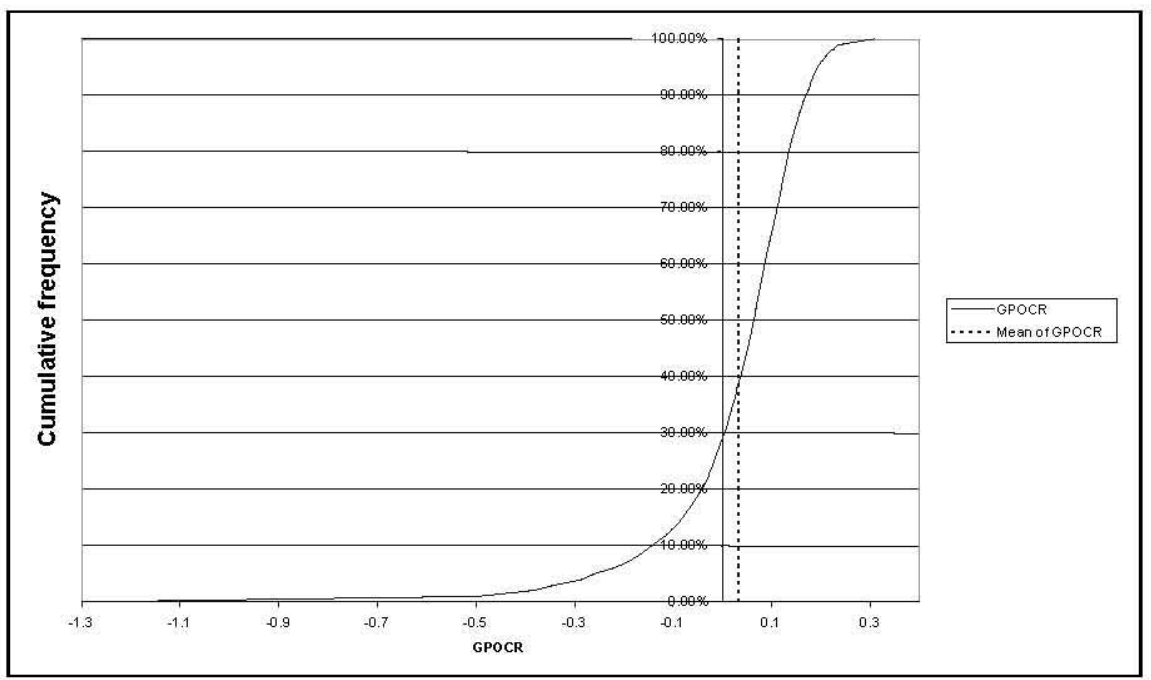

Figure 8: Cumulative distribution function of GPOCR for maize specialisation scenario, 2006/07

Source: Malan 2007

A second specialisation strategy would be to specialise in the production of milk. The assumptions are as follows:

- Maize is bought in at an average fixed price over a period of a year;

- All farmland is rented out at R200/ha;

- Sell all crop producing implements and tractors;

- Use the proceeds from the sale to buy in more producing dairy cows;

- The financial structure or net worth does not change.

The expected mean of 20 per cent with a standard deviation of less than two (2) per cent for GPOCR is indicative of a reasonable return and low risk option (Figure 9). This scenario also has no market or price risk, and is thus an acceptable option. However, due to the high level of operational risk such as a mastitis or three-daystiffness disease, it would be a better choice to diversify the business's stream of cash inflow. 


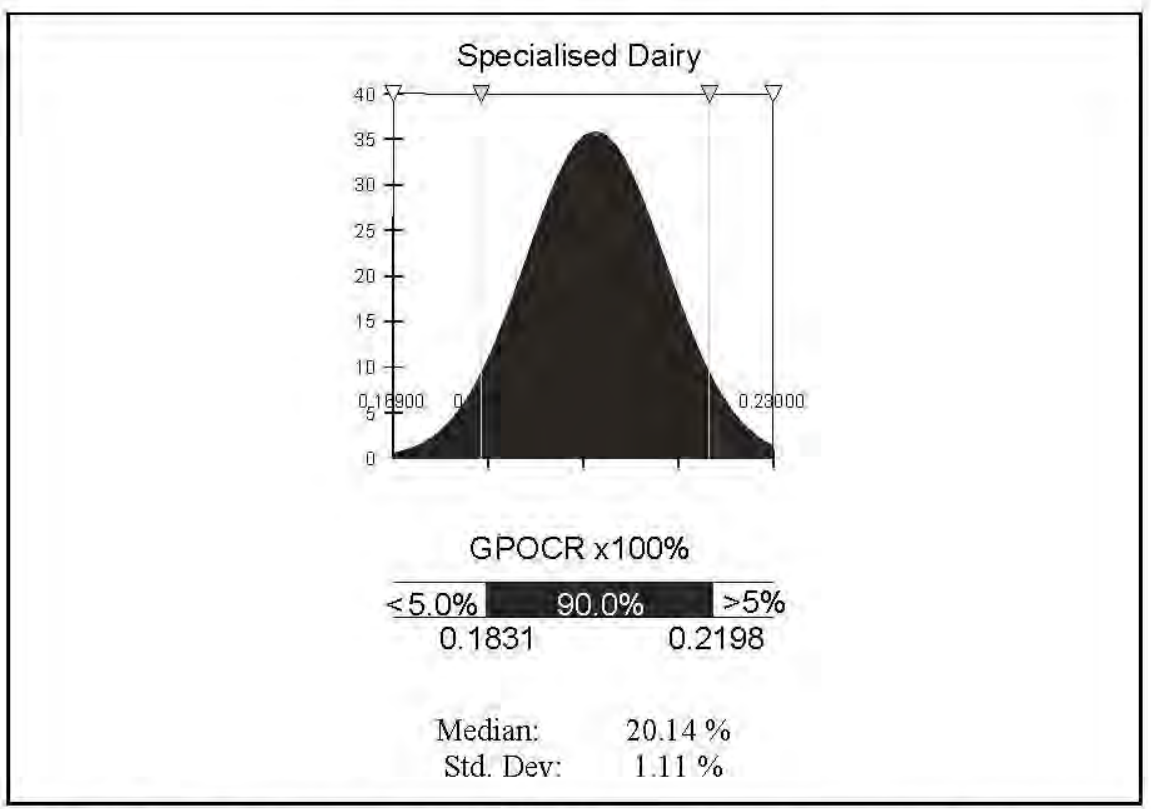

Figure 9: Rusticana farming: Simulated GPOCR fitted to a normal distribution for a specialised dairy scenario, $2006 / 07$

Source: Malan 2007

\subsubsection{Vertical integration}

As mentioned before (Table 4), milk price is one of the key drivers of profitability. It is a constraint that keeps the business from growing and increasing its profitability. Vertical integration can be a useful tool to break this constraint. Rusticana Farming is already backwards integrated in the supply chain, since most of the commodities for the dairy rations are produced and processed on the farm. Adding value to the milk is an existing opportunity for forward integration. At risk is the low longevity of milk in its natural state and the huge marketing effort needed to move nearly 15000 litres of milk daily. The model can be adapted to take these new risks into account and to determine whether the additional returns will justify these risks.

\section{CONCLUSION}

Managing a profitable commercial agricultural business requires the producer as manager to look holistically into the future, identify risks and match them with expected returns. Farmers should keep in mind that risk management does not only involve crop insurance, but should form an integral part of the business budgeting 
and planning cycle. In this regard, the balanced scorecard approach in conjunction with proper strategic planning can play a major role.

Financial statements and indicators are not historical facts, but instruments to forecast the effect of a particular risk management strategy on the business and as a real-time management tool showing the state of the business as it unfolds. The financial model proposed in this article serves this purpose, since it reflects the effect of a change in any of the input parameters in the financial statements and key performance measures. The combination of scenario planning and Monte Carlo simulation matches the identified risks and return outcomes. Graphical presentations of such risk-outcome results are a useful visual tool in forecasting possible future outcomes of a business. Simulation techniques and sensitivity analyses are useful to identify the main drivers of volatility in the business.

Farmers should realise that risk reducing strategies do not necessarily improve risk efficiency. Risk efficiency is improved if income (utility) is increased with, if necessary, tolerable increase in risk. Farmer entrepreneurs must decide whether they are using risk management strategies to reduce risk and/or to maximise expected returns. This is especially applicable in the use of futures markets, for example, Safex. The risks farmers face could offset one another if used wisely. When used in a strategy to increase expected returns, the farmer could enter into speculation with a resultant increase in risk (improved risk efficiency), while on the other hand the farmer could reduce risk to such an extent that returns become uneconomical (risk inefficiency). It is, therefore, important to match up the risk and return of each management strategy, which is where simulation techniques can be of great assistance.

With scenario modelling, all types of risks and risk mitigating strategies could be set up for the model, thereby helping farmers make informed decisions in anticipation of future outcomes. The Rusticana case study indicates that using fixed priced contracts for maize bought in and sold could reduce price risk, but in turn, this strategy reduces the expected returns dramatically. By not fixing the maize buy-in and selling price, the standard deviation for gross profit on cash revenue increased, but not to such an extent that would deter even a risk-averse manager from following this strategy.

Even in its crude form, this model, using Monte Carlo simulation techniques, is able to give a good visual interpretation of risk in the farming business. The intention with the model is not to be an exact measurement tool, but if it stimulates thinking and discussion on the risks involved with different strategies, then it has fulfilled its purpose. One of the advantages of such a model is that it simplifies understanding of often complex and unclear financial information. This should, however, be developed further to make it more user friendly. 


\section{NOTES}

1 Rusticana, P.O. Box 231, Bethal, 2310. rusticana@mweb.co.za.

2 Professor and ABSA Chair in Agribusiness: Dept. of Agricultural Economics, Extension and Rural Development, University of Pretoria, Pretoria, 0002 South Africa. andre.louw@up.ac. za.

3 Professor: Dept. of Agricultural Economics, Extension and Rural Development, University of Pretoria, Pretoria, 0002 South Africa. chris.blignaut@up.ac.za.

4 The reader can consult sources listed in the reference section.

5 Gross profit on cash revenue (GPOCR) is the total cash revenue minus total cash expense, not including depreciation/depletion and income taxes, divided by total cash revenue. GPOCR is more commonly referred to as gross margin ratio (Ferguson 1990).

6 Coefficient of variation equals SD/Mean.

7 Un-levered Return on Investment (UROI) index is the profit or loss before taxes plus interest expense paid divided by the value of total assets (Ferguson 1990).

8 Return on Assets (ROA) is also termed as Return on Investment at Fair Market Value (ROI ( FMV) by Ferguson (1990) and can be defined as the after-tax profit (or loss) divided by the value of total assets at fair market value, with the answer expressed as a percentage.

9 EBITDA index is calculated by dividing EBITDA by the amount of debt that must be paid during the same fiscal year (Malan 2007).

10 The debt payment index is expressed in a percentage, and is total debt principal and interest payments required annually, divided by total revue for the same year (Fergus on 1990).

11 Liquidity index is also expressed in percentage and is the total Rand value of current assets at fair market value divided by the total of current liabilities (Ferguson 1990).

12 TopRank software from Palisade.

13 Of the variable costs, feed costs are the dominant cost (Malan 2007).

\section{REFERENCES}

Anonymous, 2008. Glacier money market-Class B. Sanlam fund description. Available from: http:/www.sanlam.co.za/NR/rdonlyres/e7c4usvx5sz566fc6iffa4f4xtzgsoktnpat2ob3ydhvst 34ycpj2f7zkfoopmirzqxrwbjsujeu4ltco53jjq2tdxf/MoneyMarketFund.pdf (Accessed on 23 December 2008).

Atwood, J.A. and Buschena, D.E. 2003. Evaluating the magnitudes of financial transactions costs on risk behavior. Agricultural Systems, February 2003, 75(2), 235-249.

Casavant, K. 1984. Economics and agricultural management. Virginia: Reston.

Clement, R.T. and Reilly, T. 2001. Making hard decisions. Boston: Duxbury.

Dismukes, R. and Harwood, J. 2000. Farmers sharpen tools to confront business risks. Available from: www.usda.org. (Accessed on 25 April 2005).

Ferguson, R.C. 1990. Managing for profit in commercial agriculture. New Jersey: Prentice Hall.

Ferguson, R.C. 2006. Applying debt to equity Ratio. The Ferguson Ag Report. 1 February. Subscribed at www.thefergusongroupltd.com.

Gudbrand, L. 2003. Assisting whole-farm decision-making through stochastic budgeting. Agricultural Systems, 76(2), 399-414. 
Hailu, G., Jeffrey, S. and Unterschultz, J. 2005. Cost efficiency for Alberta and Ontario dairy farms: An Interregional Comparison. Canadian Journal of Agricultural Economics, 53(2), $141-160$.

Hardaker, J.B., Huirne, R.B.M.,Anderson, J.R. and Lien, G. 2004. Copingwith risk in agriculture. 2nd edition. Cambridge, MA: CABI Publishing.

Harwood, J., Heifner, R., Coble, K., and Somwaru, A. 1999. Managing risk in farming: Concepts, research and analysis. Economic Research Services, USDA. Available at: www.usda.org. (Accessed on 25 April 2005).

Holmes, A. 2002. Risk management. Oxford: Capstone.

Kars, A.A. 2003. Application of balanced scorecard for the agricultural extension service in KwaZuh-Natal. MBA dissertation, University of Pretoria.

Kulak, K., Neilson, H.M. and Strandbergh, E. 2004. Economic values for production and nonproduction traits in Nordic dairy cattle populations Calculated by Stochastic Simulation. Acta Agriculturae Scandinavica: Section A, Animal Science, 54(3), 127-138.

Lohano, H.D. and King, R.P. 2009. A Stochastic Dynamic Programming Analysis of farmland investment and financial management. Canadian Journal of Agricultural Economics, 57(4), $575-600$.

Louw, A. 2002. Application of modern risk management techniques in agricultural financing. Proc. Fertiliser Society of South Africa.

Malan, D.J.C. 2007. Risk management for successful commercial agriculture. Unpublished MBA thesis. Pretoria: University of Pretoria

Maree, D.A. 2007. Development of different technical, economic and financial benchmarks as management tool for intensive milk producers on the Highveld of South Africa. Unpublished MSc thesis. Pretoria: University of Pretoria.

Miccolis, J.A., Hively, K., and Merkley, B.W. 2001. Enterprise risk management: Trends and emerging practices. Toronto: Canadian Institute of Chartered Accountants.

Mighell, R.L. and Lawrence, A. J. 1963. Vertical coordination in Agriculture. AER-19. U.S. Dept. Agr., Econ. Res. Serv. In Harwood, J., Heifner, R., Coble, K., Somwaru, A. 1999. Managing Risk in Farming: Concepts, Research and Analysis. Economic Research Services, USDA. Available at: www.usda.org.

Mosheim, R. and Lovell, C.A. Knox. 2009. Scale economies and inefficiency of US dairy farms. $A J A E$, August, 91(3), 777-794.

Olynk, N.J. and Wolf, C.A. 2009. Stochastic economic analysis of dairy cattle artificial insemination reproductive management programs. Joumal of Dairy Science, 92(3), 1290 1299.

Palisade, 2001. Advanced risk analysis for spreadsheets. Newfield, NY: Palisade Corporation.

Safex, 2007. Safex contract prices. Available from: www.safex.co.za (Accessed in 2007).

Stephens, J.J. 2001. The business of hedging. New York: Prentice Hall.

Thompson, A.A. and Strickland, A.J. 2003. Strategic management: Concepts and cases. 13th edition. New York: McGraw-Hill.

United States Department of Agriculture (USDA), 2000. Building a risk management plan. Available from fttp://www.usda.org. (Accessed on 25 April 2005).

Van Zyl, M.J., Kirsten, J.F., Coetzee, G.K. and Blignaut, C.S. 1999. Finansiering en die boer. Johannesburg: Standard Bank van Suid Afrika. 
Simulation analysis of risk management for a diversified commercial farm

Venter, L. 2003. The drivers of profitable dairy businesses. Dairy Mail, 10(8), 55.

Winston, W.L. 2003. Operations research: Applications and algorithms. Boston: Duxbury. 